\title{
Interactive comment on "Efficient removal of phosphorus and nitrogen in sediments of the eutrophic Stockholm Archipelago, Baltic Sea" by Niels A. G. M. van Helmond et al.
}

\section{Anders Stigebrandt (Referee)}

anders.stigebrandt@marine.gu.se

Received and published: 9 January 2020

This manuscript presents vertically highly resolved observations in bottom sediments of the Stockholm Archipelago with the aim to quantify removal of phosphorus and nitrogen by sediment processes. The net fluxes of $\mathrm{P}$ and $\mathrm{N}$ through the sediment-water interface determines the removals of $P$ and $N$ (the sediment sinks). These are very important at the system level and determine together with the nutrient supplies from land-based and ocean-based sources concentrations in the water column. However, in the manuscript the estimated sediment sinks are not upscaled (i.e. horizontally integrated) to the system level which makes it impossible to verify that the removal of

Printer-friendly version

Discussion paper 
$\mathrm{P}$ and $\mathrm{N}$ in the sediments is efficient as postulated in the title of the manuscript. The manuscript needs thorough revision as discussed below.

Line 29-31. This is not shown in the manuscript, see comments on Line 514-515 below.

Line 31-32. This is not shown in the manuscript and moreover it is wrong as claimed in this interactive comment, see comments on Line 479-481 and Line 481-483 below.

Interactive

comment

Line 85. There are also strong signs of increasing eutrophication in the Baltic Sea with large and increasing volume of anoxic water and corresponding large and increasing area of anoxic bottoms (Hansson et al. 2019). See also the comment on Line 475 below.

Line 96. How is $P$ removal defined? Is $P$ removal $=P$ burial $-P$ reflux? $P$ reflux is not quantified in the manuscript. Therefore, $P$ removal is not determined. Please clarify.

Line 121. This is the so-called land-based supply. But there is also a sea-based supply by inflowing surface water from the open Baltic Sea. How large is the seabased supply? This is Important for the calculation of the filter effect mentioned on Line 17, see also comments regarding Line 514-515 below.

Line 358. What is meant by hydrological restrictions? Do you mean restrictions in the water exchange due to vertical density stratification and topographical restrictions like sills? Please clarify.

Line 368-369. The small annual amplitude of $\mathrm{P}$ and $\mathrm{O} 2$ in the bottom water of Ingaröfjärden is said to be due to a nearly absent seasonal $P$ recycling. However, it is more likely due to an efficient water exchange (flushing) throughout the year. Please explain why you discard the effect of efficient flushing throughout the year. By the way, it would be fine if the sill depths for the four basins considered could be mentioned in the manuscript. Knowing these helps to interpret the flushing of the deepwater of the basins.

Line 390. Is $P$ burial $=P$ removal ? If this is the case, $P$ reflux $=0$. Please explain. See

Printer-friendly version

Discussion paper 
also comments to Line 96 above.

Line 432. Is the deeper $\mathrm{O} 2$ penetration at Ingaröfjärden due to the action of Marenzelleria?

Line 475 Continued decrease of the land-based $P$ input to the Baltic proper has not led to reduced horizontally integrated $\mathrm{P}$ concentration $\mathrm{C}$ in the surface layer in winter. On the contrary $c$ has increased by at least $25 \%$ since the 1980 s although the landbased supply has been approximately halved (e.g. Stigebrandt, 2018). The input of organic matter into the sediments has thus rather increased. The area of anoxic bottoms increased by a factor of about 6 from the period before 1999 to the period after 1999 and attained its highest value in 2018 (Hansson et al., 2019). This should be discussed in the manuscript.

Line $479-485$. The response of water column concentrations above the sediments to the sediment processes are not quantified in the present manuscript. However, there is an exception to this. This is the statement that artificial reoxygenation of bottom waters will not be a long-term effective measure towards improving the water quality of the (coastal) Baltic Sea. There is no analysis in the manuscript that supports this statement. As shown below, the statement is wrong and should be removed from the manuscript.

Citation from Line 479 - 481. "Increases in bottom water $\mathrm{O} 2$ would likely impede the observed present-day $P$ recycling pattern in the seasonally hypoxic sites (Fig. $3 c$ ), allowing thicker Fe-oxide bearing layers and a larger Fe-bound $P$ pool in the surface sediments (e.g. Slomp et al., 1996), hence a larger (semi-permanent) surface sedimentary $P$ sink."

The thickness of the Fe-oxide bearing layers is determined by the oxygen penetration depth L. Cai and Sayles (1996) presented the following relationship between oxygen penetration depth $\mathrm{L}$, benthic oxygen flux FO2 across the sediment-water interface and bottom water oxygen concentration [O2]bw:

Printer-friendly version

Discussion paper 
Here $\theta$ and Ds are the porosity and diffusivity of $\mathrm{O} 2$ in sediment, respectively.

Equation (1) shows that the thickness $L$ of the oxidized layer on top of the sediment varies with [02]bw and, allowing for some inertia, the minimum thickness L=Lmin should occur approximately when [O2]bw attains its minimum. This means that Lmin can be increased by increasing the minimum bottom water oxygen concentration [O2]bw which is in accordance with the statement on Line 479-481.

However, the following statement (on Line 481-483) is presented without any proof of its validity for the Baltic Sea.

Citation from Line 481-483. "This process will, however, be delayed due to the prior deposition of organic rich sediments which results in a high upward flux of H2S (i.e. legacy of hypoxia) hindering the formation of Fe-oxides."

This statement is maybe true for highly eutrophic lakes, but it is not true for the deepwater sediments in the much less eutrophic Baltic Sea, as discussed on p. 41 in Stigebrandt (2018). Using Sediment Profile Imagery (SPI) it was observed that the sediment surface was oxygenated within a couple of months during a natural oxygenation event due to a Major Baltic Inflow (Rosenberg et al., 2016). This means that the upward flux of $\mathrm{H} 2 \mathrm{~S}$ in the Baltic Sea deepwater sediments is not large enough to hinder the formation of an oxic layer (containing Fe-oxides) on top of the sediment when the bottom water is oxygenated. Therefore Equation (1) is applicable to the deep sediments of Baltic Sea. The oxygen penetration depth $L$ can thus be increased by increasing [O2]bw by artificial reoxygenation of the bottom waters of the Baltic Sea.

The major effect of oxygenation of anoxic bottom sediments is that it stops the outflow of $P$ from the sediment. This was discussed in Stigebrandt et al. (2014), see also Almroth-Rosell et al. (2015) who show that the phosphorus release rate from the sediment drastically decreased and even became negative as a result of Major Baltic In-

Printer-friendly version

Discussion paper 
flows. As shown in Stigebrandt (2018), artificial reoxygenation of bottom waters should be a rapid and long-term effective measure towards reducing the eutrophication and improving the water quality of the open Baltic Sea and coastal areas with good water exchange with the open sea so that local effects of local land-based nutrient supplies are small. This disproves the following statement (on Line 483-485) in the manuscript.

Citation from Line 483 - 485 "This also explains why artificial reoxygenation of bottom waters (e.g. Stigebrandt and Gustafsson, 2007) will not be a long-term effective measure towards improving the water quality of the (coastal) Baltic Sea."

Line 516 . What is meant by "control" in the sentence "continue to actively reduce and control nutrient inputs"

Line 514-515. In the manuscript it is postulated but not shown that the sediments are efficient filter. This would require that estimates of the $\mathrm{N}$ and $\mathrm{P}$ sinks (tonnes year-1) for the whole area were related to the total supply of nutrients (tonnes year-1), i.e. the supply from both land-based and sea-based sources.

\section{References}

Almroth-Rosell, E., Eilola, K., Kuznetzov, I., Hall, P.O.J., and Meier, H.E., 2015. A new approach to model oxygen dependent benthic phosphate fluxes in the Baltic Sea. Journal of Marine Systems, 144, 127-141.

Cai, W.J., and Sayles, F.L., 1996. Oxygen penetration depths and fluxes in marine sediments. Mar. Chem. 52, 123-131.

Hansson, M., Viktorsson, L., and Andersson, L., 2019. Oxygen survey in the Baltic Sea 2018 - Extent of anoxia and hypoxia, 1960 - 2018. SMHI, Report Oceanography No 65, $11 \mathrm{pp}+2$ Appendices.

Printer-friendly version

Rosenberg, R., Magnusson, M., Stigebrandt, A., 2016: Rapid re-oxygenation of Baltic Sea sediments following a large inflow. AMBIO, 45, 130-132.

Discussion paper 
Stigebrandt, A., 2018: On the response of the Baltic proper to changes of the total phosphorus supply. Ambio, 47:31-44.

Stigebrandt, A., Rahm, L., Viktorsson, L., Ödalen, M., Hall, P.O.J., Liljebladh, B., 2014: A new phosphorus paradigm for the Baltic proper. AMBIO, 43:634-643.

Interactive comment on Biogeosciences Discuss., https://doi.org/10.5194/bg-2019-376, 2019. 